Original article

\title{
Genetic parameters and genetic trends in the Chinese x European Tiameslan composite pig line. II. Genetic trends
}

\author{
Siqing ZhANG ${ }^{\mathrm{a} *}$, Jean-Pierre BIDANEL ${ }^{\mathrm{a} * *}$, Thierry BuRLOT ${ }^{\mathrm{b}}$, \\ Christian Legaulta ${ }^{a}$, Jean NAveau ${ }^{\mathrm{b}}$ \\ a Station de génétique quantitative et appliquée, Institut national de la recherche \\ agronomique, 78352 Jouy-en-Josas Cedex, France \\ ${ }^{b}$ Pen Ar Lan, B.P. 3, 35380 Maxent, France
}

(Received 25 June 1999; accepted 8 December 1999)

\begin{abstract}
The Tiameslan line was created between 1983 and 1985 by mating Meishan $\times$ Jiaxing crossbred Chinese boars with sows from the Laconie composite male line. The Tiameslan line has been selected since then on an index combining average backfat thickness (ABT) and days from 20 to $100 \mathrm{~kg}$ (DT). Direct and correlated responses to 11 years of selection were estimated using BLUP methodology applied to a multiple trait animal model. A total of 11 traits were considered, i.e.: ABT, DT, body weight at $4(\mathrm{~W} 4 \mathrm{w}), 8(\mathrm{~W} 8 \mathrm{w})$ and $22(\mathrm{~W} 22 \mathrm{w})$ weeks of age, teat number (TEAT), number of good teats (GTEAT), total number of piglets born (TNB), born alive (NBA) and weaned (NW) per litter, and birth to weaning survival rate (SURV). Performance data from a total of 4881 males and 4799 females from 1341 litters were analysed. The models included both direct and maternal effects for ABT, W4w and W8w. Male and female performances were considered as different traits for W22w, DT and ABT. Genetic parameters estimated in another paper (Zhang et al., Genet. Sel. Evol. 32 (2000) 41-56) were used to perform the analyses. Favourable phenotypic $(\Delta P)$ and direct genetic trends $\left(\Delta G_{d}\right)$ were obtained for post-weaning growth traits and ABT. Trends for maternal effects were limited. Phenotypic and genetic trends were larger in females than in males for ABT (e.g. $\Delta G_{d}=-0.48$ vs. $-0.38 \mathrm{~mm} /$ year), were larger in males for W22W ( $\Delta G_{d}=0.90$ vs. $0.58 \mathrm{~kg} /$ year $)$ and were similar in both sexes for DT $\left(\Delta G_{d}=-0.54\right.$ vs. -0.55 day/year). Phenotypic and genetic trends were slightly favourable for W4w, W8w, TEAT and GTEAT and close to zero for reproductive traits.

pigs / genetic trend / performance trait / reproductive trait / Chinese breed

* Permanent address:

Institute of Animal Science and Husbandry, Shanghaï Academy of Agricultural Science, 2901, Beidi street, 201106 Shanghaï, China.

** Correspondence and reprints

E-mail: bidanel@dga.jouy.inra.fr
\end{abstract}


Résumé - Paramètres génétiques et évolutions génétiques dans la lignée composite sino-européenne Tiameslan. II. Évolutions génétiques. La lignée Tiameslan a été créée entre 1983 et 1985 en inséminant des truies de la lignée composite mâle Laconie par de la semence de verrats croisés Meishan $\times$ Jiaxing. Elle a depuis lors été sélectionnée sur un indice combinant l'épaisseur moyenne de lard dorsal (ELD) et la durée d'engraissement de 20 à $100 \mathrm{~kg}$ (DE). Les réponses directes et corrélatives à 11 années de sélection ont été estimées en utilisant la méthodologie du BLUP appliquée à un modèle animal multicaractère. Un total de 11 caractères a été considéré: ELD, DT, les poids corporels à $4(\mathrm{P} 4 \mathrm{~s}), 8(\mathrm{P} 8 \mathrm{~s})$ et $22(\mathrm{P} 22 \mathrm{~s})$ semaines d'âge, le nombre total de tétines (TET), le nombre de bonnes tétines (BTET), les nombres de porcelets nés totaux (NT), nés vivants (NV) et sevrés (SEV) par portée, le taux de survie naissance-sevrage (SURV). Les performances de 4881 mâles et 4799 femelles issus de 1341 portées ont été analysées. Les modèles utilisés pour ELD, P4s et P8s incluaient des effets génétiques directs et maternels. Les performances mâles et femelles ont été considérées comme des caractères différents pour P22s, DE et ELD. Les paramètres génétiques utilisés étaient ceux estimés dans le premier article de la série (Zhang et al., Genet. Sel. Evol. 32 (2000) 41-56). Les caractères de croissance post-sevrage et ELD présentaient des évolutions favorables des valeurs phénotypiques et des effets génétiques directs $\left(\Delta G_{d}\right)$. Les évolutions des effets maternels étaient limitées. Les évolutions phénotypiques et génétiques étaient plus élevées chez les femelles que chez les mâles pour $\operatorname{ELD}\left(\Delta G_{d}=-0,48\right.$ vs. $\left.-0,38 \mathrm{~mm} / \mathrm{an}\right)$, étaient plus élevées chez les mâles pour P22s ( $\Delta G_{d}=0,90$ vs. $\left.0,58 \mathrm{~kg} / \mathrm{an}\right)$ et étaient similaires dans les deux sexes pour DE $\left(\Delta G_{d}=-0,54\right.$ vs. $-0,55$ jour/an). Les évolutions phénotypiques et génétiques étaient légèrement favorables pour $\mathrm{W} 4 \mathrm{w}, \mathrm{W} 8 \mathrm{w}$, TET et BTET et proches de zéro pour les caractères de reproduction.

porcin / évolution génétique / caractère de production / caractère de reproduction / race chinoise

\section{INTRODUCTION}

Large improvements in growth and carcass traits have been obtained over the last decades in the main pig populations. Further gains are likely to be limited, particularly for carcass traits. As a consequence, genetic improvement for other economically important traits, such as reproductive and meat quality traits, has received increasing interest from breeders. Unfortunately most reproductive traits have low heritabilities and are consequently difficult to improve through selection [30]. The use of some highly prolific native breeds from China such as Meishan, Jiaxing, Erhualian, Fengjing or Min, has been proposed as an alternative to increase sow reproductive performance $[1,14,18,23]$. However, their use as a component of the maternal genotype in crossbreeding systems is not straightforward, due to their poor growth and carcass performances [1].

This problem may be overcome by creating a Chinese $\times$ European composite line and selecting it for growth and carcass traits [1]. The Chinese $\times$ European Tiameslan line was created in 1983 by the Pen Ar Lan breeding company and has been selected since then for production traits. The purpose of this study was to estimate genetic trends in the Tiameslan line after 12 years of selection. 


\section{MATERIAL AND METHODS}

The Tiameslan line was created in 1983 by mating 21 Meishan $\times$ Jiaxing F1 boars to 55 multiparous sows from the Laconie line. No immigration occurred later. Sows were allowed to produce only one litter until 1988 and have been kept for several litters as in a standard nucleus herd since then. The size of the line changed from 12 boars and around 50 sows in early generations to 15 boars and more than 200 sows in recent years.

Sows were distributed in 21 farrowing batches. Piglets were identified at birth and the numbers of piglets born alive, stillborn, crossfostered and weaned were recorded. With the exception of animals born in small litters and of a limited number of runt piglets, all male and female animals were performance tested between 8 and 22 weeks of age. They were given ad libitum access to two successive diets containing $17.5 \%$ crude protein and $3230 \mathrm{kcal}$ of DE. $\mathrm{kg}^{-1}$ until 4 months of age and then $17 \%$ crude protein and $3250 \mathrm{kcal} \mathrm{DE} \cdot \mathrm{kg}^{-1}$. Animals were weighed at weaning at 4 weeks of age, at the beginning and at the end of the test period and measured for backfat thickness (BT) and teat number on the same day as final weight. BT was measured on each side of the spine at the levels of the shoulder, the last rib and the hip joint. Breeding animals were selected on an index comprising the average of the six BT measurements (ABT), adjusted to a $100 \mathrm{~kg}$ basis, and days on test (DT). DT was computed as the difference between the age at the end and at the beginning of the test period, adjusted to 100 and $20 \mathrm{~kg}$, respectively. Some selection on teat number (truncation selection of young candidates), litter size (animals from small litters were not performance tested) and, since 1990, on coat colour (coloured breeding animals were culled) and on the genotype at the RN locus (eradication of the RN-allele [19]) was also performed. More details on the creation and selection of the Tiameslan line can be found in [37].

Phenotypic trends were estimated over all generations using the performances of a total of 10390 pigs from 1454 litters. The distribution of pigs tested according to year of birth is given in Table I. A total of 11 traits were analysed in this study: ABT and DT as defined above, weight at 4 weeks (W4w), 8 weeks (W8w) and 22 weeks (W22w) of age, total teat number (TEAT), number of good teats (GTEAT), the total number of piglets born (TNB), born alive (NBA) and weaned (NW) per litter and survival rate from birth to weaning $($ SURV), defined as the ratio $100 \times \mathrm{NW} / \mathrm{TNB}$. Means and standard deviations for the 11 traits studied are given in [37].

Because genetic (co)variances and parent-offspring covariances can vary in early generations of crossbreeding, data and pedigrees from F1 and F2 pigs were discarded from the estimation of genetic parameters and genetic trends [37]. Genetic trends were hence estimated from year 3 to year 12 (reproductive traits) or 13 (performance traits). The performances of a total of 9680 pigs (4881 males and 4799 females) from 1341 litters were considered. Genetic trends were estimated by averaging breeding values of animals with records at each generation (until 1988) or each year (after 1988). Breeding values were computed using the multivariate individual animal models that fitted the data best in variance component analyses [37]. The model used for each performance trait is given in Table II. Male and female performances were considered as the same trait for W4w, W8w, TEAT and GTEAT, but as different traits for W22w, 
DT and ABT. The model included both direct and maternal genetic effects for W4w, W8w and ABT and only direct effects for the other traits. Models can be written in matrix notation:

$$
\mathbf{y}=\mathbf{X} \beta+\mathbf{Z a}+\mathbf{W} \mathbf{p}+\mathbf{e}
$$

Table I. Distribution of pigs recorded according to year of birth.

\begin{tabular}{cccc}
\hline $\begin{array}{c}\text { Generation or } \\
\text { year of birth }\end{array}$ & \multicolumn{2}{c}{ Performance traits } & $\begin{array}{c}\text { Reproductive } \\
\text { Traits }\end{array}$ \\
\cline { 2 - 3 } & Males & Females & \\
\hline 1 & 232 & 243 & 55 \\
2 & 247 & 257 & 72 \\
3 & 106 & 93 & 36 \\
4 & 129 & 116 & 58 \\
5 & 354 & 324 & 69 \\
6 & 220 & 245 & 130 \\
7 & 242 & 284 & 167 \\
8 & 573 & 531 & 147 \\
9 & 538 & 482 & 192 \\
10 & 451 & 402 & 179 \\
11 & 710 & 629 & 200 \\
12 & 732 & 798 & 149 \\
13 & 706 & 746 & - \\
\hline
\end{tabular}

Table II. Models used for performance traits and teat number.

\begin{tabular}{|c|c|c|c|c|c|c|c|c|}
\hline \multirow[b]{2}{*}{ Trait $^{(1)}$} & \multirow{2}{*}{\multicolumn{2}{|c|}{$\begin{array}{r}\text { Fixed effects } \\
\text { Batch } \begin{array}{r}\text { Sex } \times \\
\text { batch }\end{array}\end{array}$}} & \multicolumn{3}{|c|}{ Covariates } & \multicolumn{3}{|c|}{ Random effects } \\
\hline & & & Age Weight & NBA & Inbreeding & $\begin{array}{l}\text { Direct } \\
\text { BV }\end{array}$ & $\begin{array}{c}\text { Maternal } \\
\text { BV }\end{array}$ & $\begin{array}{c}\text { Common } \\
\text { birth } \\
\text { litter }\end{array}$ \\
\hline $\begin{array}{l}\text { W4w } \\
\text { W8w } \\
{\text { W } 22 w_{f}} \text { W22w }_{m} \\
\mathrm{DT}_{f} \\
\mathrm{DT}_{m} \\
\mathrm{ABT}_{f} \\
\mathrm{ABT}_{m} \\
\text { TEAT } \\
\text { GTEAT }\end{array}$ & $\begin{array}{l}\sqrt{ } \\
\sqrt{ } \\
\sqrt{ } \\
\sqrt{ } \\
\sqrt{ } \\
\sqrt{ } \\
\sqrt{ }\end{array}$ & $\begin{array}{l}\sqrt{ } \\
\sqrt{ }\end{array}$ & $\begin{array}{l}\sqrt{ } \\
\sqrt{ } \\
\sqrt{ } \\
\sqrt{ }\end{array}$ & $\begin{array}{l}\sqrt{ } \\
\sqrt{ }\end{array}$ & $\begin{array}{l}\sqrt{ } \\
\sqrt{ } \\
\sqrt{ } \\
\sqrt{ } \\
\sqrt{ } \\
\sqrt{ }\end{array}$ & $\begin{array}{l}\sqrt{ } \\
\sqrt{ } \\
\sqrt{ } \\
\sqrt{ } \\
\sqrt{ } \\
\sqrt{ } \\
\sqrt{ } \\
\sqrt{ } \\
\sqrt{ } \\
\sqrt{ }\end{array}$ & $\begin{array}{l}\sqrt{ } \\
\sqrt{ }\end{array}$ & $\begin{array}{l}\sqrt{ } \\
\sqrt{ } \\
\sqrt{ } \\
\sqrt{ } \\
\sqrt{ } \\
\sqrt{ } \\
\sqrt{ } \\
\sqrt{ } \\
\sqrt{ } \\
\sqrt{ }\end{array}$ \\
\hline
\end{tabular}


with :

$$
\mathbf{E}\left[\begin{array}{l}
\mathbf{a} \\
\mathbf{p} \\
\mathbf{e}
\end{array}\right]=\left[\begin{array}{l}
0 \\
0 \\
0
\end{array}\right] \text { and } \operatorname{Var}\left[\begin{array}{l}
\mathbf{a} \\
\mathbf{p} \\
\mathbf{e}
\end{array}\right]=\left[\begin{array}{ccc}
\mathbf{G}_{\mathbf{a}} & \mathbf{0} & \mathbf{0} \\
\mathbf{0} & \mathbf{G}_{\mathrm{p}} & \mathbf{0} \\
0 & 0 & \mathbf{R}
\end{array}\right]
$$

where $\mathbf{y}, \beta, \mathbf{a}, \mathbf{p}$ and $\mathbf{e}$ are vectors of observations, fixed effects, additive genetic effects, birth litter effects and residuals, respectively. $\mathbf{X}, \mathbf{Z}$ and $\mathbf{W}$ are incidence matrices relating observations to the above mentioned vectors. $\mathbf{G}_{\mathbf{a}}, \mathbf{G}_{\mathbf{p}}$ and $\mathbf{R}$ are variance-covariance matrices of additive genetic, birth litter and residual effects, respectively. The structures of variance-covariance matrices depend on the trait considered. The structures of $\mathbf{R}$ and $\mathbf{G}_{\mathbf{p}}$ matrices are as follows:

$$
\mathbf{R}=\left[\begin{array}{cc}
\mathbf{I}_{\mathbf{m}} \sigma_{\mathbf{e}_{\mathbf{m}}}^{2} & \mathbf{0} \\
\mathbf{0} & \mathbf{I}_{\mathbf{f}} \sigma_{\mathbf{e}_{\mathbf{f}}}^{2}
\end{array}\right] \text { and } \mathbf{G}_{\mathbf{p}}=\left[\begin{array}{cc}
\mathbf{I}_{\mathbf{m}} \sigma_{\mathbf{p}_{\mathbf{m}}}^{2} & \mathbf{B} \sigma_{\mathbf{p}_{\mathrm{mf}}} \\
\mathbf{B} \sigma_{\mathbf{p}_{\mathbf{m f}}} & \mathbf{I}_{\mathbf{f}} \sigma_{\mathbf{p}_{\mathbf{f}}}^{2}
\end{array}\right]
$$

for W22w, DT, ABT and GTEAT,

$$
\mathbf{R}=\mathbf{I} \sigma_{\mathbf{e}}^{2} \text { and } \mathbf{G}_{\mathbf{p}}=\mathbf{I} \sigma_{\mathbf{p}}^{2} \text { for W4w, W8w and TEAT, }
$$

where $\mathbf{I}, \mathbf{I}_{\mathbf{m}}$ and $\mathbf{I}_{\mathbf{f}}$ are identity matrices, $\mathbf{B}$ is a rectangular matrix linking male and female progeny of a litter, $\sigma_{\mathbf{p}_{\mathbf{m}}}^{2}, \sigma_{\mathbf{e}_{\mathrm{m}}}^{2}, \sigma_{\mathbf{p}_{\mathrm{f}}}^{2}, \sigma_{\mathbf{e}_{\mathrm{f}}}^{2}, \sigma_{\mathrm{p}}^{2}$ and $\sigma_{\mathbf{e}}^{2}$ are the common birth litter and the residual variances for males, females and both sexes respectively; $\sigma_{\mathbf{p}_{\mathbf{m f}}}$ is the common birth litter covariance between male and female traits. The structures of $\mathbf{G}_{\mathbf{a}}$ matrices are as follows:

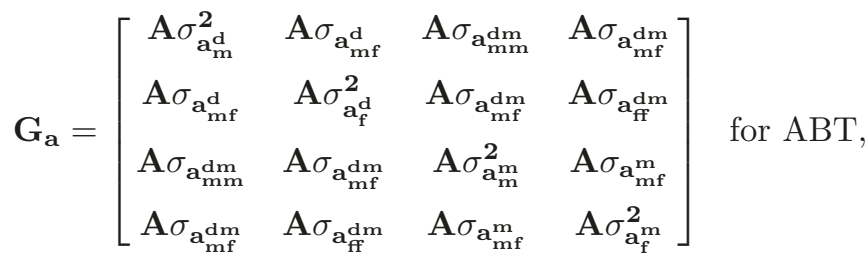

$$
\begin{aligned}
& \mathbf{G}_{\mathbf{a}}=\left[\begin{array}{cc}
\mathbf{A} \sigma_{\mathbf{a}^{\mathrm{d}}}^{2} & \mathbf{A} \sigma_{\mathbf{a}^{\mathrm{dm}}} \\
\mathbf{A} \sigma_{\mathbf{a}^{\mathrm{dm}}} & \mathbf{A} \sigma_{\mathbf{a}^{\mathrm{m}}}^{2}
\end{array}\right] \text { for W4w and W8w, } \\
& \mathbf{G}_{\mathbf{a}}=\left[\begin{array}{cc}
\mathbf{A} \sigma_{\mathbf{a}_{\mathbf{m}}^{\mathrm{d}}}^{2} & \mathbf{A} \sigma_{\mathbf{a}_{\mathrm{mf}}^{\mathrm{d}}} \\
\mathbf{A} \sigma_{\mathbf{a}_{\mathrm{mf}}^{\mathrm{d}}} & \mathbf{A} \sigma_{\mathbf{a}_{\mathrm{f}}^{\mathrm{d}}}^{2}
\end{array}\right] \text { for W22w, DT and GTEAT, } \\
& \mathbf{G}_{\mathbf{a}}=\mathbf{A} \sigma_{\mathbf{a}}^{2} \text { for TEAT, }
\end{aligned}
$$

where $\mathbf{A}$ is the relationship matrix, $\sigma_{\mathbf{a}_{\mathbf{i}}^{\mathbf{j}}}^{\mathbf{2}}$ is the additive genetic variance for direct $(j=d)$ or maternal $(j=m)$ effects for sex $i(i=m$ for males, $i=f$ for females and is removed when the same trait is considered for both sexes); $\sigma_{\mathbf{a}}^{\mathbf{d m m}}$, $\sigma_{\mathbf{a}_{\mathrm{ff}}}^{\mathrm{dm}}, \sigma_{\mathbf{a}_{\mathbf{m f}}^{\mathrm{dm}}}, \sigma_{\mathbf{a}^{\mathrm{dm}}}$ are covariances between direct and maternal additive genetic 
effects for males, females, between males and females and averaged over sexes, respectively; $\sigma_{\mathbf{a}_{\mathbf{m f}}^{\mathrm{d}}}$ and $\sigma_{\mathbf{a}_{\mathbf{m f}}^{\mathrm{m}}}$ are covariances between male and female traits for direct and maternal additive genetic effects, respectively.

The model used for TNB, NBA, NW and SURV included parity and farrowing batch as fixed effects, the additive genetic value and the permanent environment of the sow as random effects, as well as age within parity and sow and/or litter inbreeding coefficient as covariables.

Breeding values were obtained as back solutions from restricted maximum likelihood analyses performed using version 4.2 of the VCE software [25]. Fixed effects were tested using the PEST software [13] using models without maternal effects.

Simplified models, i.e. a model with a single trait for both sexes with maternal effects (model 2) and models without maternal effects considering male and female performance either as two different traits (model 3) or a single trait (model 4) were also used for ABT and DT in order to study the impact of the model used to describe the data on estimated genetic trends.

\section{RESULTS}

Fixed effects and covariables. Batch effects were significant for all traits, but did not show any consistent seasonal trend. Males were slightly heavier at weaning than females $(+10 \mathrm{~g} ; P<0.001)$ and had similar weights at 8 weeks of age in all generations. Conversely, males were lighter than females at 22 weeks of age in early generations $(-3 \mathrm{~kg} ; P<0.001$, during the first 3 years), but became heavier $(+2 \mathrm{~kg} ; P<0.01$, from year 6 to 12$)$ than females in later ones. A sex $\times$ year interaction, only partially due to a scale effect, was obtained for ABT: females were much fatter in early generations $(+4 \mathrm{~mm} ; P<0.001)$ during the first 3 years, but the difference between sexes then decreased and amounted to $1.5 \mathrm{~mm}(P<0.001)$ in later years. An increased number of littermates was associated with lighter weights at 4,8 and 22 weeks of age (respectively, $-0.03 ;-0.07$ and $-0.16 \mathrm{~kg} /$ piglet for $\mathrm{W} 4 \mathrm{w}, \mathrm{W} 8 \mathrm{w}$ and $\mathrm{W} 22 \mathrm{w})$. The effects of inbreeding are shown in Table III. The direct inbreeding coefficient had detrimental effects on postweaning growth traits (W8w, W22w and DT), but a negative, i.e. favourable, effect on ABT. Both direct and maternal inbreeding had unfavourable effects on litter size, but only the maternal inbreeding was significant.

Genetic trends. Phenotypic $(\Delta P)$ trends from year 1 to year 13 and genetic $(\Delta G)$ trends for performance traits and teat number from year 3 to 13 are shown in Figure 1. Year 3 was chosen as the base generation in order to allow the comparison of phenotypic and genetic trends. W4w slightly decreased until year 4 and then regularly increased (Fig. 1a). The average phenotypic trend was $0.19 \mathrm{~kg} /$ year from year 3 to 13 . The estimated genetic trend was close to zero for both direct $(+0.03 \mathrm{~kg} /$ year $)$ and maternal $(+0.01 \mathrm{~kg} /$ year $)$ effects. W8w decreased from year 1 to 3 , remained almost constant until year 11 and then slightly increased. Annual genetic trends were low (respectively, +0.06 and $+0.04 \mathrm{~kg} /$ year for direct and maternal effects), thus indicating that selection had a limited effect on early postweaning growth rate (Fig. 1b). Conversely, after an initial decrease between generation 1 and 2 , large improvements were 
Table III. Effect of $10 \%$ inbreeding of litter and dam on performance.

\begin{tabular}{lcccc}
\hline Trait & \multicolumn{2}{c}{ Pig/litter inbreeding } & \multicolumn{2}{c}{ Dam inbreeding } \\
\hline W4w (kg) & 0.09 & $\mathrm{~ns}$ & -0.07 & $\mathrm{~ns}$ \\
W8w (kg) & -0.16 & $\mathrm{~ns}$ & -0.03 & $\mathrm{~ns}$ \\
W22w (kg) & -1.6 & $* * *$ & 1.4 & $* * *$ \\
ABT (mm) & -0.08 & $\mathrm{~ns}$ & -0.02 & $\mathrm{~ns}$ \\
DT (d.) & 1.3 & $* * *$ & -1.3 & $* * *$ \\
TEAT & -0.12 & $*$ & 0.09 & $*$ \\
GTEAT & -0.34 & $* * *$ & 0.27 & $* * *$ \\
TNB & -0.27 & $\mathrm{~ns}$ & -0.82 & $* *$ \\
NBA & -0.35 & $\mathrm{~ns}$ & -0.57 & + \\
NW & -0.12 & $\mathrm{~ns}$ & -0.61 & $*$ \\
SURV (\%) & -0.06 & $\mathrm{~ns}$ & 0.00 & $\mathrm{~ns}$ \\
\hline
\end{tabular}

(1) See Table II for explanation of the traits. ns $=$ non significant; $+=P<0.10$; * $=P<0.05 ;{ }^{* *}=P<0.01 ; * * *=P<0.001$.

obtained for W22w and DT, particularly in males (Figs. 1c and 1d). Yearly phenotypic and genetic trends were, respectively, 0.72 and $0.90 \mathrm{~kg}$ for $\mathrm{W} 22 \mathrm{w}$, -1.18 and -0.54 days for DT in males and 0.20 and $0.58 \mathrm{~kg}$ for $\mathrm{W} 22 \mathrm{w},-1.21$ and -0.55 days for DT in females. ABT substantially decreased during the first 9 years and then remained almost constant. Phenotypic trends amounted to - 1.27 and $-0.62 \mathrm{~mm} /$ year, respectively, in males and females from year 1 to 9 and were almost zero from year 9 to year 13. Genetic gains were mainly due to direct effects and amounted to $-0.59 \mathrm{~mm} /$ year between year 3 and year 9 and to -0.14 and $-0.05 \mathrm{~mm} /$ year from year 9 to 13 in females ( $-0.48 \mathrm{~mm} /$ year over the whole period considered). Corresponding values for males were respectively, $-0.54 ;-0.05$ and $-0.38 \mathrm{~mm} /$ year. Phenotypic and genetic trends for TEAT were limited (respectively +0.06 and +0.05 teat/year; Fig. 1f) whereas GTEAT increased slightly, but regularly over the years $(+0.15$ and +0.09 teat/year for $\Delta P$ and $\Delta G$, respectively).

Phenotypic and genetic trends for reproductive traits are shown in Figure 2. Litter size at birth remained almost constant over the period considered. $\Delta P$ for TNB and NBA were, respectively, - 0.07 and - 0.02 piglets/litter/year, whereas $\Delta G$ amounted to -0.03 piglets/litter/year for both traits. The trends were similar for NW (respectively, 0.08 and 0.03 piglets/litter/year for $\Delta P$ and $\Delta G)$. SURV slightly decreased until year 5 and then remained constant. The estimated genetic trend was also close to zero ( -0.6 and 0.1 percentage points for $\Delta P$ and $\Delta G$, respectively).

The effects of the model used to describe the data are shown for ABT and DT in Figure 3. Estimated genetic trends for ABT were reduced when maternal effects were ignored. Including maternal effects for DT had a very limited impact on estimated genetic trends in males and led to slightly lower estimated response to selection in females. Conversely, considering male and female performance as a single trait led to a higher estimated genetic trend for ABT $(-0.52 \mathrm{~mm} /$ year as compared to a sex average of $-0.43 \mathrm{~mm} /$ year when one trait/sex is considered) and a slightly lower trend for DT ( -0.51 day/year vs. a sex average of -0.55 day/year). 


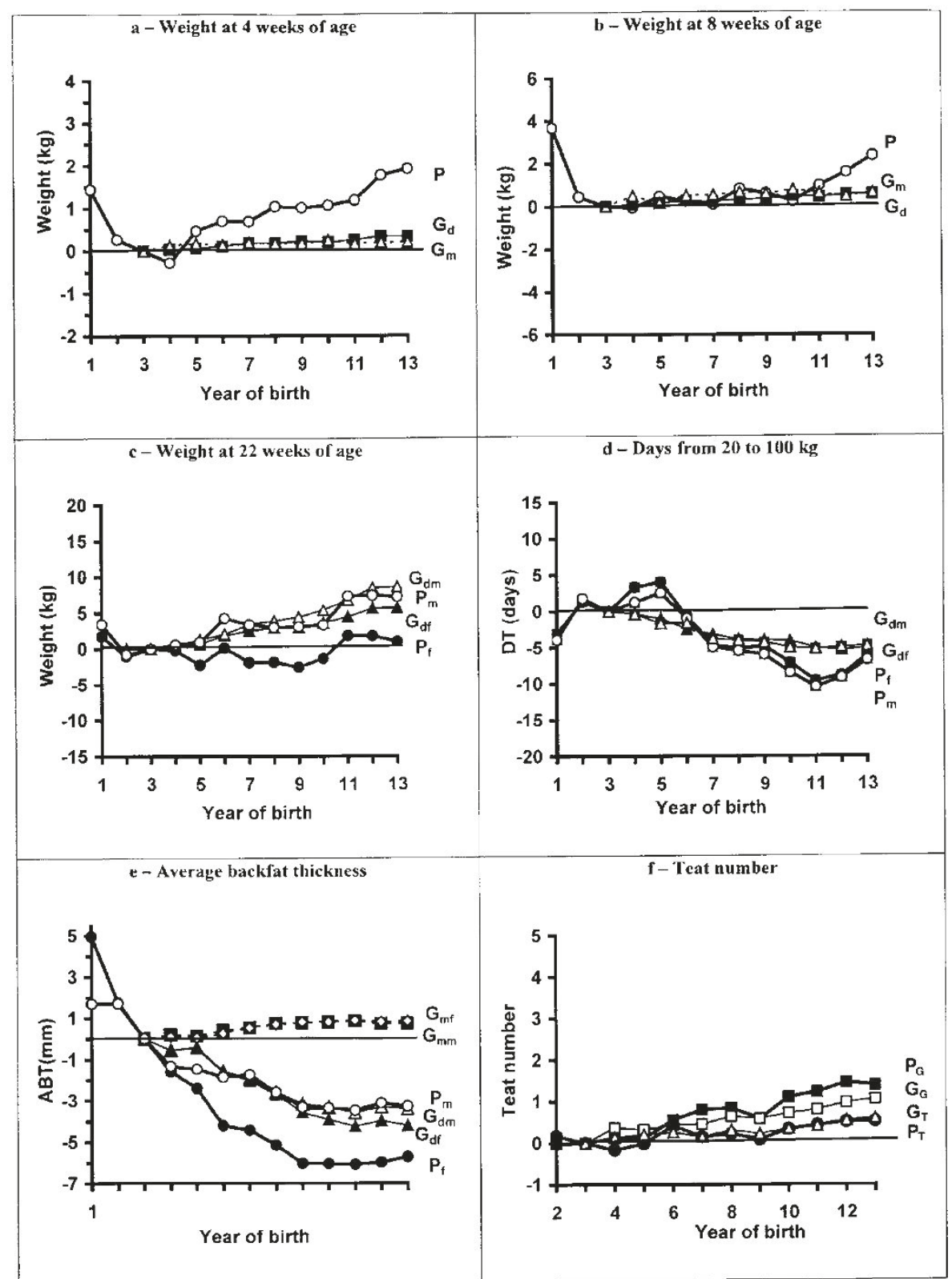

Figure 1. Estimated phenotypic and genetic trends for production traits and teat number in the Tiameslan line.

$\mathbf{P}_{\mathbf{M}}, \mathbf{P}_{\mathbf{F}}, \mathbf{P}=$ phenotypic trends for males, females and in both sexes, respectively; $\mathbf{G}_{\mathbf{d m}}, \mathbf{G}_{\mathbf{d f}}, \mathbf{G}_{\mathbf{d}}=$ genetic trends for direct effects in males, females and in both sexes, respectively; $\mathbf{G}_{\mathbf{m m}}, \mathbf{G}_{\mathbf{m f}}, \mathbf{G}_{\mathbf{m}}=$ genetic trends for maternal effects in males, females and in both sexes, respectively; $\mathbf{P}_{\mathbf{G}}, \mathbf{P}_{\mathbf{T}}, \mathbf{G}_{\mathbf{G}}, \mathbf{G}_{\mathbf{T}}=$ phenotypic and genetic trends (direct effects) for the total number and the number of good teats, respectively.

The $y$ axis of each graph approximately represents 4 standard deviations of each trait. 


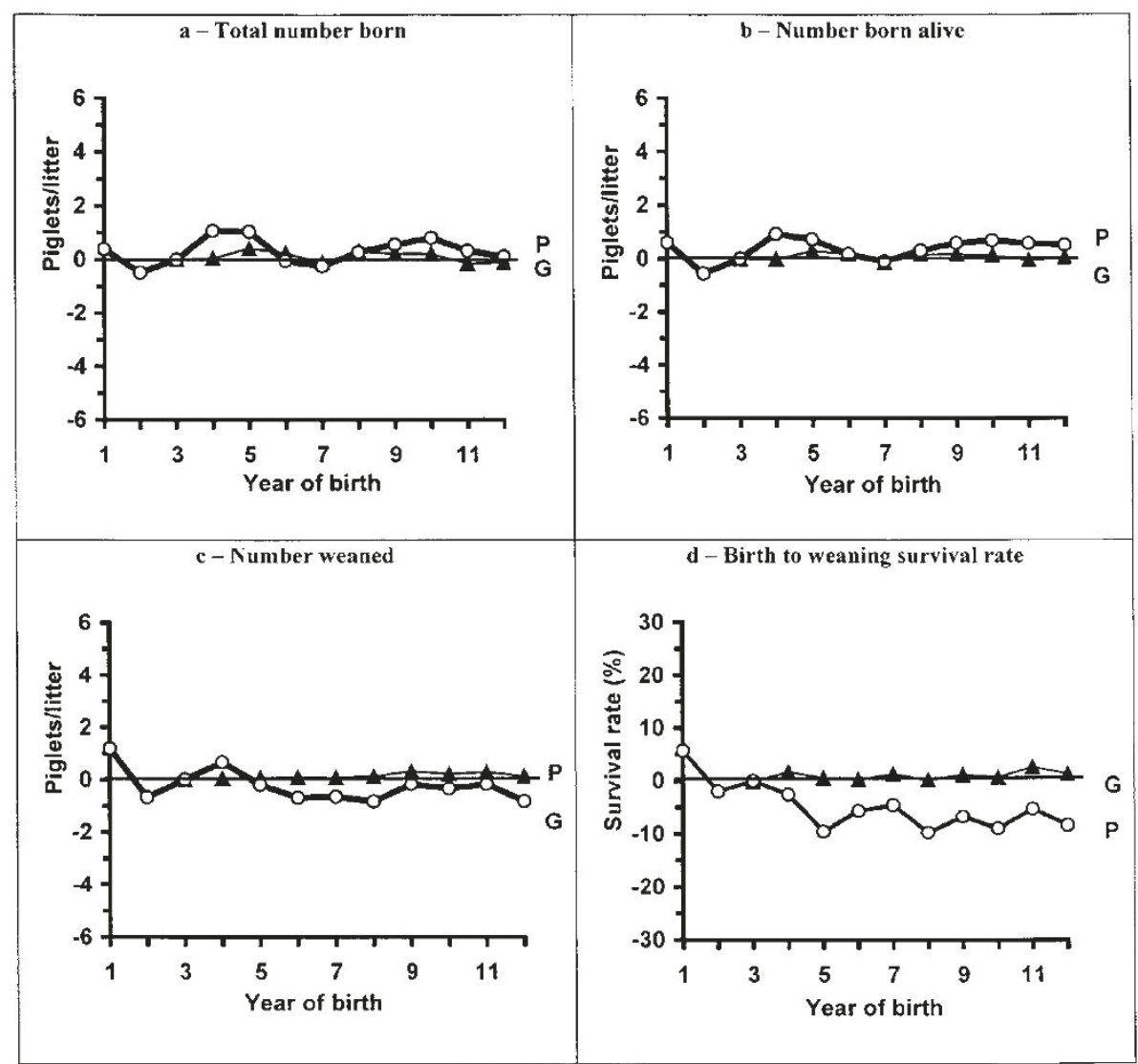

Figure 2. Estimated phenotypic and genetic trends for reproductive traits in the Tiameslan line.

$\mathbf{P}=$ phenotypic trend; $\mathbf{G}=$ genetic trend.

The $y$ axis of each graph approximately represents 4 standard deviations of each trait.

\section{DISCUSSION}

Methodology. Since the groundwork of Blair and Pollak [3] and Sorensen and Kennedy [31, 32], BLUP methodology applied to animal models (AM) has become the standard method to estimate genetic trends in selected populations. The major reasons for this are the desirable properties of BLUP-AM estimators which, under certain conditions, adequately partition phenotypic trend into its genetic and environmental components. Necessary conditions are an exhaustive use of the data on which selection was based, the use of a correct model to describe data, a proper structure of the base population (i.e. no selection, linkage equilibrium) and knowledge of dispersion parameters of this base population $[12,16,32]$.

These conditions are unfortunately never fulfilled in practical situations. First of all, dispersion parameters are unknown and genetic trends are estimated using prior values or point estimates, generally REML estimates, of 


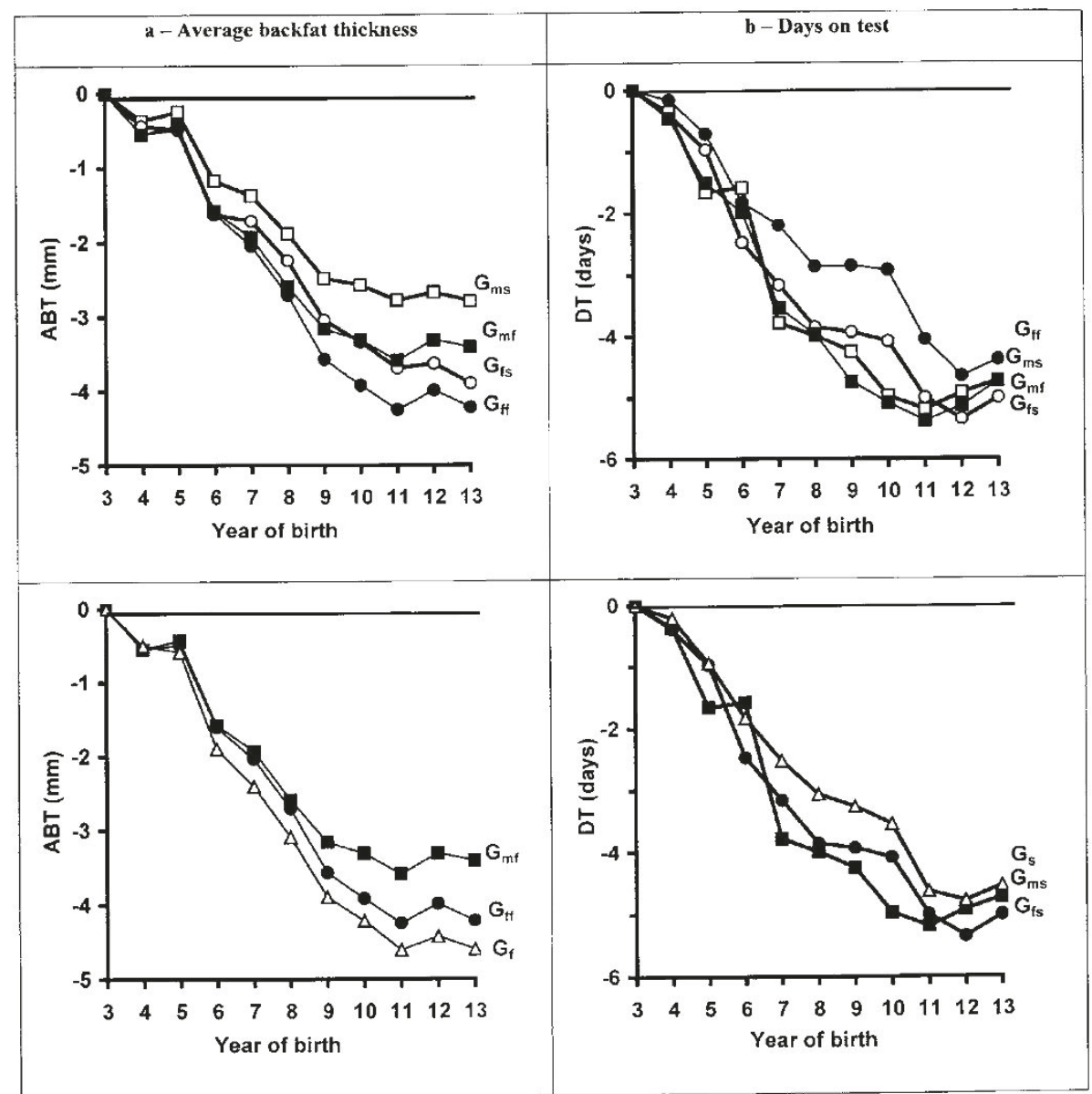

Figure 3. Effect of the model used to describe the data on estimated response to selection.

$\mathbf{G}_{\mathbf{m f}}, \mathbf{G}_{\mathrm{ff}}, \mathbf{G}_{\mathbf{m s}}, \mathbf{G}_{\mathbf{f s}}=$ genetic trends in males (m) and females (f) estimated from the full model with maternal effects (f) and a simplified (s) model ignoring maternal effects; $\mathbf{G}_{\mathbf{f}}, \mathbf{G}_{\mathbf{s}}=$ genetic trend estimated considering a single trait for both sexes using full (f) or a simplified (s) model.

the true parameters. As emphasised by Thompson [34] and more recently by Ollivier [26], BLUP animal model estimates of selection response then depend on these prior values. The sensitivity of estimates is dependent on the model used to describe the data and on the experimental design, particularly on the degree of overlap between generations. In an extreme situation with no overlap, the estimate of direct selection response is a linear function of the prior heritability value [34]. In the present case, there was no overlap on the male side, but an important overlap on the female side after year 4 , since only $33 \%$ of the litters produced between year 5 and 13 were first parity litters. As a consequence, estimates of genetic trends in generation 3 and 4 are likely to be more sensitive than the values of genetic parameters and to have a lower 
precision. However, the sensitivity of estimated genetic trends to prior values of genetic parameters may also depend on the model used to describe the data. More complex models such as maternal effects models are likely to be associated with an increased sensitivity to prior values because, for example, the degree of overlap between generations may be correct for direct effects, but poor for maternal effects.

As illustrated by the results obtained on ABT and DT, the model used to describe the data also has a notable impact on estimates of response to selection. It can be validly argued, based on likelihood ratio tests, that the model with maternal effects for ABT was significantly better than the model involving only direct additive effects [37] and that it consequently gave better estimates of genetic trends. However, things may not necessarily be so simple, because estimates are likely to be more sensitive to the prior parameter values used than simpler models and because estimates of (co)variance components are less accurate in more sophisticated models than in simpler ones. Using these estimates may in some instances lead to a larger bias than that related to the use of a simpler, but more robust, model. Little has been done until recent years on the way to find the best model for prediction. Tools such as crossvalidation techniques or, in the Bayesian framework, the comparison of posterior predictive distribution of future observations to real data or substantive knowledge [9] are appealing methods for model checking.

One reason for the lower robustness of complex models is that point estimates of genetic parameters are used in REML/BLUP methodology. This problem has a conceptually simple solution in a Bayesian framework, where inferences about breeding values are made from the marginal posterior distribution of selection response, i.e. by integrating out of the joint posterior distribution of fixed effects and variance components, which are considered as nuisance parameters [11]. As emphasised by Sorensen et al. [33], this can be viewed as a weighted average of BLUP predictions where the weighting function is the marginal posterior distribution of (co)variance components, i.e. all possible estimates of (co)variance components multiplied by their probability. This approach requires the integration of joint posterior densities with respect to nuisance parameters, which has become feasible with the development over the last few years of Monte-Carlo based procedures such as the Gibbs sampling $[8,10]$. This methodology has been successfully used several times to estimate responses to selection with univariate animal models (e.g. [4, 33]). Conversely, until now little has been published in the multivariate case, for example, to estimate correlated responses to selection. One possible explanation may be that the choice of a prior distribution is much less straightforward than in the univariate case and because estimated response may be more sensitive to prior distributions than in the simple univariate case.

Another important issue arising when estimating response to selection in a composite population concerns the way to consider early generations of selection. Important changes in the average performance of the Tiameslan line clearly occurred in the first three generations. These changes can be attributed to the lower amount of heterosis effects expressed in F2 as compared to F1 animals, to environmental changes, but also to the selection practised in these early generations. This early selection was ignored because early generations of crossbreeding are associated with changes in (co)variance components which could 
not be considered. Methodological tools allowing to consider these changes have been developed in recent years [21, 22], but their practical use remains difficult, particularly under dominance inheritance, because of the large number of parameters involved.

Estimated genetic trends may also be biased because the polygenic infinitesimal model does not correctly describe genetic variation in the Tiameslan line. In particular, the MU gene with a major effect on average backfat thickness was evidenced in the Laconie line by Le Roy et al. [20]. This gene has a dominant lean allele and is likely to segregate in the Tiameslan population. In this situation, genetic trends estimated ignoring the dominant major gene are likely to be biased. The increasing frequency and maybe the fixation of the favourable allele at this locus or at other QTLs may also partially explain the lower response to selection during the last few years. However, the selection for white coat color and the eradication of the unfavourable allele at the RN locus [19] conducted since the beginning of the nineties are also likely to contribute to this lower genetic trend for ABT.

Results. Whatever the model used, estimated genetic trends for production traits are much higher than most literature results based on the same methodology. Yearly trends of $-0.26 \mathrm{~mm}$ and $-0.12 \mathrm{~mm}$ in the French Large White breed, of $-0.16 \mathrm{~mm}$ and $-0.11 \mathrm{~mm}$ in the French Landrace were reported by Tixier and Sellier [35] and Ducos and Bidanel [7], respectively. Similar trends were obtained in Canada [17] and Switzerland [15]. Similarly, average daily gain increased at the rate of 0.6 to $2.9 \mathrm{~g}$, i.e. -0.05 to -0.3 days on test in the studies of Tixier and Sellier [35], Hofer et al. [15] and Ducos and Bidanel [7]. Larger values (-0.66 and -0.78 days at $90 \mathrm{~kg}$ in the Large White and Landrace breeds) were reported by Kennedy [17]. It has to be noted that the larger trends obtained in the Tiameslan line as compared to the above mentioned results are largely, but not entirely, due to a higher genetic variability. For instance, yearly trends for ABT amounted to -0.2 genetic standard deviation units in the Tiameslan line vs. -0.08 to -0.17 genetic standard deviation units in Large White or Landrace populations.

Phenotypic and genetic trends for litter size at birth and at weaning were close to zero, in spite of the negative genetic correlations between NW and both ABT and DT. These trends tend to show that no recombination loss [5, 6 ] has occurred in advanced generations of crossbreeding, which agrees with the results obtained by Bidanel [2] in Large White $\times$ Meishan crosses. The lack of unfavourable correlated response to selection on growth rate and lean content is more surprising. Given the negative genetic correlations between both $\mathrm{ABT}$ and DT and litter size, a deterioration of about 0.06 piglets/litter/year could be expected. Some selection for litter size was performed by selecting candidates for selection in large litters. However, the selection differential applied (+0.3 piglets/litter) was too weak to entirely explain the lack of deterioration of prolificacy. Several other hypotheses can be proposed to explain this lack of degradation. The genetic antagonism between performance and reproductive traits may have been overestimated because the model used to describe the data was not correct, for instance because dominance effects could not be properly taken into account. Major genes or QTLs segregating in the Tiameslan line might also explain this unexpected result through pleiotropic effects or effects of linked QTLs. However, little is known on the effects of the 
major genes such as MU and RN loci on litter size. Similarly, the effects of the backfat loci recently evidenced in the Chinese crossbred population (see [29] for a review) have currently not been estimated. Another candidate region might be the region of the KIT gene responsible for dominant white coat colour in pigs, whose orthologous region in mice is known to have large effects on reproductive traits [24], and where ovulation rate QTLs have recently been evidenced [27, $28,36]$.

\section{CONCLUSION}

This study shows that it is possible to efficiently select a Chinese $\times$ European composite line for production traits while maintaining high genetic merit for reproductive traits. The initial handicap of these lines for production traits may therefore be reduced by selection and make a Chinese $\times$ European composite line profitable as a component of the maternal genotype in pig crossbreeding systems. Recent advances in the knowledge of genes responsible for the differences between Chinese and European breeds for economically important traits (reviewed by Rothschild [29]) should be very helpful in the future for more efficient selection strategies and better genetic control of these lines.

\section{ACKNOWLEDGEMENT}

The thesis of Zhang Siqing was financed by a grant from the INRA "Direction scientifique des productions animales".

\section{REFERENCES}

[1] Bidanel J.P., Bases zootechniques et génétiques de l'utilisation en élevage intensif des races prolifiques chinoises - cas du porc Meishan, Doctoral Thesis, Institut national agronomique Paris-Grignon, France, 1988, 194 pp.

[2] Bidanel J.P., Estimation of crossbreeding parameters between Large White and Meishan porcine breeds. III. Dominance and epistatic components of heterosis on reproductive traits, Genet. Sel. Evol. 25 (1993) 639-657.

[3] Blair H.T., Pollak E.J., Estimation of genetic trend in a selected population with and without the use of a control population, J. Anim. Sci. 58 (1984) 878-886.

[4] Blasco A., Bidanel J.P., Sorensen D., A bayesian analysis of genetic parameters and selection response for litter size components in pigs, Genetics 149 (1998) 301-306.

[5] Dickerson G.E., Experimental approaches in utilising breed resources, Anim. Breed. Abstr. 37 (1969) 191-202.

[6] Dickerson G.E., Inbreeding and heterosis in animals, in: Proceedings of the Animal Breeding and Genetics Symposium in honor of Dr J.L. Lush, American Society of Animal Science and Dairy Science Association, Champaign, Illinois, 1973, pp. $54-77$.

[7] Ducos A., Bidanel J.P., Utilisation d'un modèle animal multi-caractère pour estimer l'évolution génétique de six caractères de croissance, carcasse et qualité de la viande entre 1977 et 1990, dans les races porcines Large White et Landrace Français, in: $25^{\text {es }}$ Journées de la Recherche Porcine en France, 2-4 février 1993, Institut technique du porc, Paris, pp. 59-64. 
[8] Gelfand A.E., Smith A.F.M., Sampling-based approaches to calculating marginal densities, J. Am. Stat. Assoc. 85 (1990) 398-409.

[9] Gelman A., Carlin J.B., Stern H.S., Rubin D.B., Bayesian data analysis, Chapman \& Hall, London, 1997, 526 pp.

[10] Geman S., Geman D., Stochastic relaxation, Gibbs distribution and Bayesian restoration of image, IEEE Transactions on Pattern Analysis and Machine Intelligence 6 (1984) 721-741.

[11] Gianola D., Foulley J.L., Fernando R.L., Prediction of breeding values when variances are not known, Génét. Sél. Evol. 18 (1986) 475-484.

[12] Gianola D., Fernando R.L., Im S., Foulley J.L., Likelihood estimation of quantitative genetic parameters when selection occurs: models and problems, Genome 31 (1989) $768-777$.

[13] Groeneveld E., Kovac M., Wang T., PEST, a general purpose BLUP package for multivariate prediction and estimation, in: Proceedings of the 4th World Congress on genetics applied to livestock production, 23-27 July, Edinburgh, Scotland, 1990, Vol. XIII, pp. 488-491.

[14] Haley C.S., Ashworth C.J., Lee G.J., Wilmut I., Aitken R.P., Ritchie W., British studies of the genetics of prolificacy in the Meishan pig, in: Molénat M., Legault C. (Eds.), Chinese pig symposium, 5-6 July, Toulouse, France, 1990, pp. 8397.

[15] Höfer A., Hagger C., Kunzi N., Genetic evaluation of on-farm tested pigs using an animal model. II. Prediction of breeding values with a multiple trait model, Livest. Prod. Sci. 30 (1992) 83-98.

[16] Im S., Fernando R.L., Gianola D., Likelihood inferences in animal breeding under selection: a missing-data theory view point, Genet. Sel. Evol. 21 (1989) 399-414.

[17] Kennedy B.W., Genetic evaluation of swine using the animal model, in: Proc. 38th Annual Meeting Eur. Assoc. Anim. Prod., Lisbon, Portugal, 1987, Commission on animal genetics.

[18] Legault C., Caritez J.C., L'expérimentation sur le porc chinois en France. I-Performances de reproduction en race pure et en croisement, Génét. Sél. Evol. 15 (1983) 225-240.

[19] Le Roy P., Naveau J., Elsen J.M., Sellier P., Evidence for a new major gene influencing meat quality in pigs, Genet. Res. 55 (1990) 33-40.

[20] Le Roy P., Elsen J.M., Naveau J., Etude de la variabilité génétique de l'adiposité dans la lignée Laconie, in: $22^{\text {es }}$ Journées de la Recherche Porcine en France, 30 January-1st February 1990, Institut technique du porc, Paris, pp. 11-16.

[21] Lo L.L., Fernando R.L., Grossman M., Covariance between relatives in multibreed populations: additive model, Theor. Appl. Genet. 87 (1993) 1215-1228.

[22] Lo L.L., Fernando R.L., Grossman M., Theory of modelling means and covariances in a two-breed population with dominance, Theor. Appl. Genet. 90 (1995) 49-62.

[23] Mc Laren D.G., The potential of Chinese swine breeds to improve pork production efficiency in the US, Anim. Breed. Abstr. 58 (1990) 347-369.

[24] Marklund S., Kijas J., Rodriguez-Martinez H., Rönnstrand L., Funa K., Moller M., Lande D., Edfors-Lilja I., Andersson L., Molecular basis for the dominant white phenotype in the domestic pig, Genome Res. 8 (1995) 826-833.

[25] Neumaier A., Groeneveld E., Restricted maximum likelihood estimation of covariances in sparse linear models, Genet. Sel. Evol. 30 (1998) 3-26.

[26] Ollivier L., On the use of animal models in the analysis of selection experiments, Genet. Sel. Evol. 31 (1999) 135-148.

[27] Rathje T.A., Rohrer G.A., Johnson R.K., Evidence for quantitative trait loci affecting ovulation rate in pigs, J. Anim. Sci. 75 (1997) 1486-1494. 
[28] Rohrer G.A., Ford J.J., Wise T.H., Vallet J.L., Christenson R.K. Identification of quantitative trait loci affecting female reproductive traits in a multigeneration Meishan-White composite swine population. J. Anim. Sci. 77 (1999) 1385-1391.

[29] Rothschild M.F., Identification of quantitative trait loci and interesting candidate genes in the pig: progress and prospects, in: Proceedings of the 6th World Congress on Genetics Applied to Livestock Production, 11-16 January, University of New England, Armidale, Australia, 1998, Vol. 26, pp. 403-409.

[30] Rothschild M.F., Bidanel J.P., Biology and genetics of reproduction, in: Rothschild M.F., Ruvinsky A. (Eds.), The genetics of the pig, CAB International, Wallingford, Oxon, UK, 1998, pp. 313-343.

[31] Sorensen D.A., Kennedy B.W., Estimation of response to selection using least squares and mixed model methodology, J. Anim. Sci. 58 (1984) 1097-1106.

[32] Sorensen D.A., Kennedy B.W., Analysis of selection experiments using mixed model methodology, J. Anim. Sci. 63 (1986) 245-258.

[33] Sorensen D.A., Wang C.S., Jensen J., Gianola D., Bayesian analysis of genetic change due to selection using Gibbs sampling, Genet. Sel. Evol. 26 (1994) 333360 .

[34] Thompson R., Estimation of realized heritability in a selected population using mixed model methods, Genet. Sel. Evol. 18 (1986) 475-484.

[35] Tixier M., Sellier P., Estimated genetic trends for growth and carcass traits in two French pig breeds, Genet. Sel. Evol. 18 (1986) 185-212.

[36] Wilkie P.J., Paszek A.A., Beattie C.W., Alexander L.J., Wheeler M.B., Schook L.B., A genomic scan of porcine reproductive traits reveals possible quantitative trait loci (QTLs) for number of corpora lutea, Mamm. Genome 10 (1999) $573-578$.

[37] Zhang S., Bidanel J.P., Burlot T., Legault C., Naveau J., Genetic parameters and genetic trends in the Chinese $\times$ European Tiameslan composite pig line. I. Genetic parameters, Genet. Sel. Evol. 32 (2000) 41-56. 